\title{
Neuromyths as a Challenge and Opportunity for the Learning and Teaching of Neuroscience ${ }^{1}$
}

Asil Ali Özdoğru²

Nursena Balatekin ${ }^{3}$

Type/Tür:

Review/Derleme

Received/Geliş Tarihi: September

4/4 Eylül 2018

Accepted/Kabul Tarihi:

December 28/28 Aralık 2018

Page numbers/Sayfa No: $483-494$

Corresponding

Author/İletişimden Sorumlu

Yazar:

asilozdogru@uskudar.edu.tr

\section{$\checkmark$ iThenticate}

This paper was checked for plagiarism using iThenticate during the preview process and before publication. / Bu çalışma ön inceleme sürecinde ve yayımlanmadan önce iThenticate yazılımı ile taranmıştır.

Copyright $(2018$ by Cumhuriyet University, Faculty of Education. All rights reserved.

\begin{abstract}
Neuromyths are misconceptions generated by misunderstanding or misquoting of facts established by neuroscience about various topics such as critical periods, bilingualism, and hemispherization. The availability and dissemination of questionable content through various traditional and new media outlets fuel the spread of neuromythical ideas. Many teachers and students around the world believe in these neuromyths, which present a great challenge and at the same time an opportunity for the meaningful learning and use of neuroscientific knowledge. Based on the research published in the last 15 years, this study provides a review of the common neuromyths, their predictors and consequences, and proposes ways to deal with them for research and education communities. Common neuromyths include the use of $10 \%$ of the brain, right- and left-brain learners, learning styles, dyslexia, classical music, and attention. Lack of knowledge, high level of interest, and ineffective learning and teaching strategies were found to contribute to the proliferation of neuromyths. Learners and teachers who are well equipped with foundational knowledge in basic sciences, information literacy skills, and effective teaching techniques can be better in identifying and eliminating neuromyths. In order to battle and suppress neuromyths, neuroscientists and educators should improve their collaboration, and learners and teachers should adopt more effective learning and teaching strategies.
\end{abstract}

Keywords: Neuroscience, misconceptions, neuromyths, learning, teaching

\section{Suggested APA Citation/Önerilen APA Atıf Biçimi:}

Özdoğru, A. A., \& Balatekin, N. (2018). Neuromyths as a challenge and opportunity for the learning and teaching of neuroscience. Cumhuriyet International Journal of Education, 7(4), 483-494. http://dx.doi.org/10.30703/cije.457302

\footnotetext{
${ }^{1}$ An earlier version of this paper was presented in 2017 at the 4th International Conference on Computational and Experimental Science and Engineering in Antalya, Turkey.

2 Dr. Öğr. Üyesi, Üsküdar Üniversitesi, İnsan ve Toplum Bilimleri Fakültesi, Psikoloji (İng.) Bölümü, İstanbul/Türkiye

Asst. Prof. Dr., Üsküdar University, Faculty of Humanities and Social Sciences, Department of Psychology (Eng.), İstanbul/Turkey

e-mail: asilozdogru@uskudar.edu.tr

ORCID ID: https:/ / orcid.org/0000-0002-4273-9394

3 Psikolog, İstanbul/Türkiye

Psychologist, İstanbul/Turkey

e-mail: nursena.balatekin@gmail.com

ORCID ID: http:/ / orcid.org/0000-0001-9630-3564
} 


\title{
Nörobilimin Öğrenimi ve Öğretimi İçin Bir Zorluk ve Fursat Olarak Nöromitler
}

\begin{abstract}
Öz
Nöromitler; kritik dönemler, çift dillilik ve yanallaşma gibi çeşitli konularda nörobilim tarafından ortaya konan olguların yanlış anlaşılması veya yanlış yorumlanmasıyla ortaya çıkan kavram yanılgılarıdır. Çeşitli geleneksel ve yeni medya organları aracılığıyla şaibeli içeriğin erişilebilirliği ve yayılması, nöromit içeren fikirlerin çoğalmasını körüklemektedir. Dünyanın farklı bölgelerinden pek çok öğretmen ve öğrencinin bu nöromitlere inanması nörobilimsel bilginin anlamlı bir şekilde öğrenilmesi ve kullanımı açısından büyük bir tehdit ve aynı zamanda bir fırsat sunmaktadır. Bu çalışmada nöromitler hakkında son 15 yılda yayınlanan araştırmalar üzerinden yaygın nöromitler, bunların yordayıcıları ve sonuçları özetlenmekte araştırma ve eğitim camiası için nöromitlerle başa çıkmanın yolları sunulmaktadır. Yaygın nöromitler, beynin \%10'unun kullanımı, sağ ve sol beyinle öğrenme, öğrenme stilleri, disleksi, klasik müzik ve dikkat gibi konuları içermektedir. Bilgi eksikliği, yüksek düzeyde ilgi ile etkisiz öğrenme ve öğretme stratejileri nöromitlerin çoğalmasına neden olmaktadır. Temel bilimler ile ilgili esaslı bilgi birikimi olan, bilgi okuryazarlı̆̆ becerisi ve etkili öğretim tekniklerine sahip öğrenci ve öğretmenler nöromitlerin saptanması ve ortadan kaldırılmasında daha yeterli olabilirler. Nöromitlerle savaşmak ve onları bastırmak için nörobilimciler ve eğitimciler işbirliklerini geliştirmeli ve öğrenciler ile öğretmenler daha etkili öğrenme ve öğretme stratejileri benimsemelidir.
\end{abstract}

Anahtar Kelimeler: Nörobilim, kavram yanılgıları, nöromitler, öğrenme, öğretme

\section{Introduction}

Neuroscience has attracted a great deal of attention in the past decades not only in scientific circles but also among public audience. Advance in research methodologies and technologies contributed to the proliferation of research findings and visualizations. Traditional and social media allowed these findings to be disseminated to a wide variety of individuals and groups. Even though there have been improvements in our understanding of human brain and behavior, there is more to be done on the translation and implementation of neuroscience.

Research in neuroscience offers valuable information on human cognitive functions and adds new perspectives to a variety of fields such as education, economy, management, marketing, and policy studies. The field of education benefits from neuroscientific knowledge about human learning, memory, and cognitive processes. There is broad enthusiasm among teachers for the introduction of neuroscience into education to improve their students' learning and their own teaching performance (Dekker, Lee, Howard-Jones, \& Jolles, 2012). Even though there is a great deal of interest among teachers, the use of neuroscientific research in classroom practice can be problematic.

\section{Challenge}

Research findings in neuroscience are usually complex and they need to be clearly comprehended. Transfer of these research findings from laboratories to classrooms is generally hard and should be done through controlled and science-based sources. Otherwise, there is less certain but more popular neuroscientific information that is loosely based on scientific facts. Unfortunately, this kind of popular misinformation is common among general public as well as professionals in education. There should 
be measures to prevent the damage of common fallacies about human brain mechanisms (Karakus, Howard-Jones, \& Jay, 2015). In order to face this challenge, Organisation for Economic Co-operation and Development (OECD) drew attention to the issue as part of its Brain and Learning Project (1999-2006). The project emphasized misconceptions about functions of the brain and classified them with the term "neuromyths."

\section{Neuromyths and Neurofacts}

Neuromyths are false beliefs that are not backed up by scientific evidence bases. A neuromyth is defined by OECD (2002) as "a misconception generated by a misunderstanding, a misreading, or a misquoting of facts scientifically established (by brain research) to make a case for use of brain research in education and other contexts" (p. 111). Popular neuromyths include misconceptions about critical periods, enriched environments, learning styles, use of brain, bilingualism, and hemispherization. OECD (2007) lists eight common neuromyths as the following:

1. There is no time to lose as everything important about the brain is decided by the age of three

2. There are critical periods when certain matters must be taught and learnt

3. But I read somewhere that we only use $10 \%$ of our brain anyway

4. I'm a 'left-brain', she's a 'right-brain' person

5. Let's face it-men and boys just have different brains from women and girls

6. A young child's brain can only manage to learn one language at a time

7. Increase your memory capacity!

8. Learn while you sleep!

In a more recent study with a large sample from the Unites States, researchers identified seven neuromyths, which also included the neuromyths about the use of $10 \%$ of the brain and right-brain/left-brain learners (Macdonald, Germine, Anderson, Christodoulou, \& McGrath, 2017). Other five neuromyths were about learning styles, dyslexia, classical music, and sugar and attention. Two statements about the learning styles neuromyth were (1) "Individuals learn better when they receive information in their preferred learning style", and (2) "Children have learning styles that are dominated by particular senses". Other neuromyths were (3) "A common sign of dyslexia is seeing letters backwards", (4) "Listening to classical music increases children's reasoning ability", and (5) "Children are less attentive after consuming sugary drinks and/or snacks". In the same study, even though two items about the neuromyth on motor coordination received high factor scores in connection to above neuromyths, they were not included in the group of seven because of their low item discrimination between the general public and high neuroscience exposure group. Those two items were (1) "Short bouts of motor coordination exercises can improve the integration of right and left hemispheres" and (2) "Exercises that rehearse coordination of motor-perception skills can improve literacy skills".

Lilienfeld and his colleagues (2010) identified and demystified 50 myths of popular psychology about many topics including human brain, development, memory, learning, and consciousness. The common neuromyths included \%10 brain use, left-right brain, classical music, dyslexia, learning styles, and learning while 
asleep among its list of 50 myths. These researchers also warn readers that not only psychology but also many other domains of life include plenty of myths and one needs to have mythbusting skills like self-awareness and critical thinking to eliminate them.

Neuroscience research continues to dispel these oversimplified and overgeneralized claims about human mind and brain. The neuromyths on critical and sensitive periods imply that there are short windows of influence on developing brain for certain subjects and skills. However, research on neurogenesis and neuroplasticity shows that brain adapts, grows, and changes throughout human lifespan (OECD, 2002). The 10\% and left/right-brain neuromyths are also refuted by research as our entire brain is active even during sleep and under local anesthesia, and two hemispheres are connected and work together (OECD, 2007). Even though neuroscientists use "masculine brain" and "feminine brain" terms to refer to different cognitive profiles and ways of being for men and women, there is not a substantial difference between male and female brains (Baron-Cohen, 2003). The neuromyth on one language at a time is a widely challenged belief as more and more research shows the natural capacity for children to learn multiple languages and cognitive benefits of being a multilingual over a monolingual (Adesope, Lavin, Thompson, \& Ungerleider, 2010). Contrary to the popular claims, memory enhancement and braintraining games do not lead to meaningful and permanent changes in cognitive performance and generalized improvements in intellectual function (McCabe, Redick, \& Engle, 2016; Owen et al., 2010). While learning during sleep is possible, the effects are minimal and impractical to have considerable effects on long-term memory (OECD, 2007). Other neuromyths about learning styles, dyslexia, classical music, sugar consumption, and motor coordination, which are especially common among Americans, have also been repeatedly contested by empirical research in neuroscience (Macdonald et al., 2017).

\section{Prevalence, Predictors, and Consequences}

Several studies report alarming rates of neuromyths among individuals from different backgrounds and cultures. In their study with 3877 individuals from the US, Macdonald and her colleagues (2017) found that the endorsement of neuromyths was most common among general public (68\%), followed by teachers $(56 \%)$, and even individuals with high exposure to neuroscience (46\%). Other studies also report high levels of neuromyth prevalence about learning styles (93-97\%), right-brain/leftbrain learners (71-91\%), and coordination exercises (60-88\%) among teachers in China (Pei, Zhang, Liu, Jin, \& Howard-Jones, 2015), Greece (Deligiannidi \& HowardJones, 2015), Turkey (Karakus et al., 2015; Koçak, 2018) and the United Kingdom and the Netherlands (Dekker et al., 2012). Several other studies provided similar high levels of neuromyth prevalence among prospective and in-service teachers in Germany (Düvel, Wolf, \& Kopiez, 2017), Greece (Papadatou-Pastou, Haliou, \& Vlachos, 2017), Latin America (Gleichgerrcht, Lira Luttges, Salvarezza, \& Campos, 2015), Portugal (Rato, Abreu, \& Castro-Caldas, 2013), Spain (Ferrero, Garaizar, \& Vadillo, 2016), Switzerland (Tardif, Doudin, \& Meylan, 2015), Turkey (Canbulat \& Kırıktas, 2017; Dündar \& Gündüz, 2016), and the UK (Howard-Jones, Franey, Mashmoushi, \& Liao, 2009). 
There are many factors behind the adoption of neuromyths by large groups of individuals. Although the level of general knowledge in neuroscience seems to protect individuals from neuromyths, a high level of interest and superficial knowledge about the subject may encourage the development of neuromyths (Dekker et al., 2012; Gleichgerrcht et al., 2015; Howard-Jones et al., 2009). Some of the traditional and new media outlets were found to contribute to the creation and dissemination of neuromyths. The coverage of neuroscientific studies in brief newspaper articles and questionable Internet sources seem to be exaggerated and misleading (Pasquinelli, 2012).

Neuromyths gain visibility and credibility through their usage and dissemination across various mediums. Images of brain are used to make several stories and advertisements more believable (Lindell \& Kidd, 2013). The belief on the existence of a mental state when accompanied by a brain image is called "neurorealism" (Racine, Bar-Ilan, \& Illes, 2006). The widespread availability of these images and stories is fueling the "illusion of knowing" about brain even among individuals without any neuroscience knowledge or experience (Olson \& Hergenhahn, 2009).

The gap between neuroscience research and educational practice contributes to the proliferation of neuromyths. Lack of collaboration and communication between neuroscientists and teachers create an environment conducive for neuromyths. Teachers eagerly look for neuroscientific information they can use in their classroom practice. Research shows that many teachers use Internet as their primary source of information and prefer popular sources over scientific articles (Karakus et al., 2015; OECD, 2002). Therefore, their knowledge and practice based on these sources include a variety of neuromyths.

Neuromyths have important consequences for individuals and society at large. Individuals who believe in neuromyths think that they understand the mysteries of human brain. Neuromyths provide a simplistic outlook on the complex subject of mind and behavior. Those simple but incoherent ideas would be spread by those individuals in their social circles and networks. If unchecked, those neuromyths have the potential to contaminate more and more people across various fields and backgrounds. The field of education presents a critically important environment for neuromyths. Teachers are sources of knowledge for their students and they would influence many of their students in the wrong way if they believe in neuromyths.

When teachers develop and implement classroom practices based on neuromyths, the effects and outcomes of their efforts might be negligible. The unrealistic expectations placed on instructional practices based on neuromyths can yield to costly and ineffective interventions. These "neurononsense" cause wasted time, money, and effort, which could be better invested on the development and implementation of evidence-based practices (Purdy, 2008). Teachers, policymakers, and the general public are advised to recognize the limitations of neuroscience research and to prevent the "hijacking of neuroscience" by practitioners (Coltheart, 2013). Otherwise, perception of science would degrade, while pseudoscientific ideas would prevail among public audiences. 


\section{Opportunity}

Neuromyths present a great challenge for the science and education communities. However, like all other challenges, neuromyths also have the potential to provide a moment of opportunity for all those involved. Through a joining of forces and systematic effort, neuromyths can be easily tackled. In order to answer this challenge, neuroscientists and educators should improve their communication, and learners and teachers should be supported with some basic knowledge and skills. These efforts can be advantageous for a renewed relationship among the fields as well as for an enhanced translation and application of neuroscience.

\section{Communication and Collaboration}

Neuroscience offers an improved understanding of human mind, brain, and behavior. Neuroscience and psychology provide insight on factors relevant to effective learning and teaching such as motivation, memory, self-regulation, and sleep. Teachers can, and are eager to, benefit from studies in cognitive neuroscience to help their students. There is a widespread influence of neuroscientific approaches on educational practices as seen in the example of brain-based learning. However, caution is needed in the application of complex neuroscience findings into the evaluation of learning and teaching strategies (Anderson \& Della Sala, 2012).

Uncritical acceptance of neuromyths is a threat for both neuroscience and education. Educators should be able to make judgments about the effectiveness and accuracy of neuroscientific information relevant to their practice. They should develop deeper knowledge about more secure ways to interact with research findings that emerge from cognitive neuroscience (Bellert \& Graham, 2013). Otherwise, the field of education is vulnerable to "the allure of everything neuro" (Anderson \& Della Sala, 2012, p. 6). In order to enhance the transfer and translation of neurofacts, there should be a steady collaboration between neuroscientists and educators to invent common language and shared understanding (Bellert \& Graham, 2013).

Neuromyths can be curtailed and eliminated through more functional dissemination and utilization of neuroscientific knowledge. Neuroscientists should be encouraged, assisted, and evaluated in the public communication of their studies (Illes et al., 2010). A working relationship between neuroscientists and practitioners is needed in this pursuit. Research shows that neuroscientists and educators usually have incompatible expectations about brain-based learning and divergent perspectives of each other (Edelenbosch, Kupper, Krabbendam \& Broerse, 2015). Studies and interventions in various fields such as educational neuroscience attempt to build a stronger bridge between the two parties. Cognitive psychology and educational psychology are proposed as the two fields to help bridge the gap between neuroscience and education (Im, Cho, Dubinsky, \& Varma, 2018). A multilateral and international collaborative network of scholarship and practice, as seen in the field of Mind, Brain, and Education, can provide a better context of interaction between neuroscientists, psychologists, and educators (Özdoğru, 2014).

\section{Lessons for Learners and Teachers: Pedagogical Implications}

Individuals interested in learning about neurosciences should be prepared in terms of related knowledge and skills. Basic background knowledge in natural sciences as 
well as social and behavioral sciences can help learners to answer elementary questions they would face in their readings. Formal coursework or independent studies in various areas such as chemistry, biology, psychology, and philosophy can provide a solid foundation (Presti, 2015). Neuroscience literacy among students and teachers can be improved through this kind of a more organized and comprehensive study of the field. However, it should be noted that providing students with more training on neuroscience would not simply eliminate neuromyths. For example, in an experimental study, taking an educational psychology course increased students' neuroscience literacy but did not influence their belief in neuromyths (Im et al., 2018).

Learners equipped with basic information literacy skills would be better prepared to identify and deal with misinformation. Chartered Institute of Library and Information Professionals (CILIP) defines information literacy as "knowing when and why you need information, where to find it, and how to evaluate, use and communicate it in an ethical manner" (CILIP, 2004). Learners with adequate levels of information literacy skills can check the sources of information and credibility of evidence about the neuroscientific knowledge they are learning. Providing training courses on information literacy skills can prepare learners in the identification and interpretation of neuromyths and other misinformation.

As lifelong learners, teachers should have not only the abovementioned knowledge and skills but also a set of effective teaching skills. They should organize the learning experience for learners to effectively work with their existing preconceptions and misconceptions. National Research Council (2000) offers three principles for effective teaching: (1) engaging resilient preconceptions, (2) organizing knowledge around core concepts, and (3) supporting metacognition.

Preconceptions are previous knowledge and experiences that learners may strongly believe and bring to learning environments, which can involve faulty and incorrect ideas. In order to engage preconceptions and challenge neuromyths, teachers should create opportunities for students to make their thinking visible through formative assessments and group discussions. Those prevailing conceptions should be challenged by showing students the inefficiency of their mental models in solving some of everyday examples. Through frequent guidance and feedback, students should be encouraged to develop their own ways and means of discovery.

The second principle of effective teaching is about core concepts, which are quite important in the meaningful learning of any subject matter. Teachers can help students to thoroughly learn and navigate first-order and second-order core concepts. First-order core concepts are about the scientific discipline such as physical sciences, life sciences, and engineering. Second-order concepts are about the subject of study, which in this case is neuroscience. Society for Neuroscience (2008) offers four mega and eight core concepts for neuroscience, which are presented in Table 1, and provides resources for $\mathrm{K}-12$ educators to integrate these concepts into their lesson plans. 
Table 1

Mega and Core Concepts of Neuroscience

\section{Mega Concepts}

I. The nervous system controls and responds to body functions and directs behavior

II. The nervous system structure \& function are determined by both genes \& environment throughout life

III. The brain is the foundation of the mind

IV. Research leads to understanding that is essential for development of therapies for nervous system disorders

\section{Core Concepts}

1. The brain is the body's most complex organ

2. Neurons communicate using both electrical and chemical signals

3. Genetically determined circuits are the foundation of the nervous system

4. Life experiences change the nervous system

5. Intelligence arises as the brain reasons, plans, and solves problems

6. The brain makes it possible to communicate knowledge through language

7. The human brain endows us with a natural curiosity to understand how the world works

8. Fundamental discoveries promote healthy living and treatment of disease

The third and last principle of supporting metacognition can be facilitated by a variety of instructional activities and assessments. Research shows that detailed debunking, rather than a focus on initial misinformation, can more effectively counter misconceptions (Chan, Jones, Hall Jamieson, \& Albarracín, 2017). An overstatement of misinformation can let individuals produce arguments in support of their initial misconceptions. Therefore, learners should not just passively be told that their preconceptions are wrong, but actively be involved in the generation of counterarguments about those misconceptions. In order to promote student involvement and engagement, teachers can design and guide classroom discussions either in small groups or as a whole class. Classroom discussion and discourse as a critical pedagogy practice fosters the development of critical thinking skills and the social construction of knowledge (Sarroub \& Quadros, 2015). Peer instruction and cognitive tutors can be helpful in students' learning as well. Lastly, formative assessments and frequent feedback by teachers can be instrumental in the use of assessments to support learning.

Association for Psychological Science recently started an initiative to help instructors to overcome misconceptions that students bring into introductory psychology classes (Sleek, 2018). The initiative provides a pedagogical model, free online lesson plans, and supplementary materials for instructors to use in correcting several misconceptions including three neuromyths on $\% 10$ brain use, brain training, and sugar and hyperactivity. For example, the lesson plan for $\% 10$ brain use myth includes a three-day lesson plan, which involves a concept check formative assessment, a short slide show, a large group discussion or writing activity, and two assignments that make use of small group work and short reflective essays. Through such lessons, the initiative aims to stimulate active student engagement in critical and scientific thinking about mind, brain, and behavior. 


\section{Conclusions}

Neuromyths are a new set of misconceptions about brain generated and proliferated through traditional and social media networks. Students and teachers are at the risk of being contaminated with inaccurate knowledge and ideas about human brain and behavior. This challenge can be turned into an opportunity through the employment of several action items. There should be increased collaboration among neuroscientists and practitioners in the production and utilization of scientific and practical knowledge.

Both learners and teachers should be supported with foundational knowledge and skills in the effective learning and teaching of neuroscience. Learners should be equipped with critical thinking and information literacy skills in order to effectively identify and eliminate neuromyths. Effective teachers should engage resilient preconceptions, organize knowledge around core concepts, and support metacognition among their students through a more reflective curriculum, instruction, and assessment.

\section{References}

Adesope, O., Lavin, T., Thompson, T., \& Ungerleider, C. (2010). A systematic review and meta-analysis of the cognitive correlates of bilingualism. Review of Educational Research, 80, 207-245. https://doi.org/10.3102/0034654310368803

Anderson, M., \& Della Sala S. (2012). Neuroscience in education: (An opinionated) introduction. In S. Della Sala, \& M. Anderson (Eds.), Neuroscience in education: The good, the bad and the ugly (pp. 3-12). Oxford: Oxford University Press.

Baron-Cohen, S. (2003). The essential difference: Men, women and the extreme male brain. London: Allen-Lane.

Bellert, A., \& Graham, L. (2013). Neuromyths and neurofacts: Information from cognitive neuroscience for classroom and learning support teachers. Special Education Perspectives, 22(2), 7-20.

Canbulat, T., \& Kirıktas, H. (2017). Assessment of educational neuromyths among teachers and teacher candidates. Journal of Education and Learning, 6(2), 326. https:// doi.org/10.5539/jel.v6n2p326

Chan, M., Jones, C., Hall Jamieson, K., \& Albarracín, D. (2017). Debunking: A metaanalysis of the psychological efficacy of messages countering misinformation. Psychological Science, 28, 1531-1546. https:/ / doi.org/10.1177/0956797617714579

Chartered Institute of Library and Information Professionals (CILIP) (2004). Information literacy. Retrieved from https:/ / www.cilip.org.uk/research/topics/information-literacy

Coltheart, M. (2013). Weird neuroscience: How education hijacked brain research. Learning Difficulties Australia Bulletin, 45, 1-9.

Dekker, S., Lee, N., Howard-Jones, P., \& Jolles, J. (2012). Neuromyths in education: Prevalence and predictors of misconceptions among teachers. Frontiers in Psychology. https://doi.org/10.3389/fpsyg.2012.00429

Deligiannidi, K., \& Howard-Jones, P. (2015). The neuroscience literacy of teachers in Greece. Procedia - Social and Behavioral Sciences, 174, 3909-3915. https:/ / doi.org/10.1016/j.sbspro.2015.01.1133 
Dündar, S., \& Gündüz, N. (2016). Misconceptions regarding the brain: The neuromyths of preservice teachers. Mind, Brain, and Education, 10, 212-232. https://doi.org/10.1111/mbe.12119

Düvel, N., Wolf, A., \& Kopiez, R. (2017). Neuromyths in music education: Prevalence and predictors of misconceptions among teachers and students. Frontiers in Psychology, 8. https://doi.org/10.3389/fpsyg.2017.00629

Edelenbosch, R., Kupper, F., Krabbendam, L., \& Broerse, J. (2015). Brain-based learning and educational neuroscience: Boundary work. Mind, Brain, and Education, 9(1), 40-49. https:/ / doi.org/10.1111/mbe.12066

Ferrero, M., Garaizar, P., \& Vadillo, M. (2016). Neuromyths in education: Prevalence among Spanish teachers and an exploration of cross-cultural variation.

Frontiers in Human Neuroscience, 10. https:/ / doi.org/10.3389/fnhum.2016.00496

Gleichgerrcht, E., Lira Luttges, B., Salvarezza, F., \& Campos, A. (2015). Educational neuromyths among teachers in Latin America. Mind, Brain, and Education, 9(3), 170-178. https://doi.org/10.1111/mbe.12086

Howard-Jones, P. A., Franey, L., Mashmoushi, R., \& Liao, Y.-C. (2009, September). The neuroscience literacy of trainee teachers. Paper presented at the British Educational Research Association Annual Conference, Manchester, UK.

Illes, J., Moser, M., McCormick, J., Racine, E., Blakeslee, S., \& Caplan, A. ... Weiss, S. (2010). NeuroTalk: Improving the communication of neuroscience research. Nature Reviews Neuroscience, 11(1), 61-69. https:/ / doi.org/10.1038/nrn2773

Im, S.-h., Cho, J.-Y., Dubinsky, J. M., \& Varma, S. (2018) Taking an educational psychology course improves neuroscience literacy but does not reduce belief in neuromyths. PLoS ONE, 13(2). https:/ / doi.org/10.1371/journal.pone.0192163

Karakus, O., Howard-Jones, P., \& Jay, T. (2015). Primary and secondary school teachers' knowledge and misconceptions about the brain in Turkey. Procedia Social and Behavioral Sciences, 174, 1933-1940. https:// doi.org/10.1016/j.sbspro.2015.01.858

Koçak, G. (2018, Ekim). Okul öncesi öğretmenlerinin beyin fizyolojik bilgilerinin değerlendirilmesi. II. Uluslararası Öğretmen Eğitimi ve Akreditasyon Kongresinde sunulmuş bildiri, Rize, Türkiye.

Lilienfeld, S. O., Lynn, S. J., Ruscio, J., \& Beyerstein, B. L. (2010). 50 great myths of popular psychology: Shattering widespread misconceptions about human behavior. West Sussex, UK: Wiley-Blackwell.

Lindell, A., \& Kidd, E. (2013). Consumers favor "right brain" training: The dangerous lure of neuromarketing. Mind, Brain, And Education, 7(1), 35-39.

https:/ / doi.org/10.1111/mbe.12005

Macdonald, K., Germine, L., Anderson, A., Christodoulou, J., \& McGrath, L. (2017). Dispelling the myth: Training in education or neuroscience decreases but does not eliminate beliefs in neuromyths. Frontiers in Psychology, 8. https:/ / doi.org/10.3389/fpsyg.2017.01314

McCabe, J., Redick, T., \& Engle, R. (2016). Brain-training pessimism, but appliedmemory optimism. Psychological Science in the Public Interest, 17(3), 187-191. https:// doi.org/10.1177/1529100616664716 
National Research Council (2000). How people learn: Brain, mind, experience, and school (Expanded Edition). Washington, DC: The National Academies Press. https:// doi.org/10.17226/9853

Olson, M., \& Hergenhahn, B. (2009). An introduction to theories of learning. Upper Saddle River, NJ: Pearson/Prentice Hall.

Organisation for Economic Co-operation and Development (OECD) (2002). Understanding the brain: Towards a new learning science. Paris: OECD Publications. https:/ / doi.org/10.1787/9789264174986-en

Organisation for Economic Co-operation and Development (OECD) (2007). Understanding the brain: The birth of a learning science. Paris: OECD Publications. https:/ / doi.org/10.1787/9789264029132-9-en

Owen, A. M., Hampshire, A., Grahn, J. A., Stenton, R., Dajani, S., Burns, A. S., ... Ballard, C. G. (2010). Putting brain training to the test. Nature, 465(7299), 775778. https://doi.org/10.1038/nature09042

Özdoğru, A. A. (2014). Mind, Brain, and Education: An emerging transdisciplinary field of learning and development. The Journal of Neurobehavioral Sciences, 1(3), 95-96. https:// doi.org/10.5455/jnbs.1408373410

Papadatou-Pastou, M., Haliou, E., \& Vlachos, F. (2017). Brain knowledge and the prevalence of neuromyths among prospective teachers in Greece. Frontiers in Psychology, 8. https://doi.org/10.3389/fpsyg.2017.00804

Pasquinelli, E. (2012). Neuromyths: Why do they exist and persist? Mind, Brain, and Education, 6(2), 89-96. https:/ / doi.org/10.1111/j.1751-228x.2012.01141.x

Pei, X., Zhang, S., Liu, X., Jin, Y., \& Howard-Jones, P. (2015). Teachers' understanding about the brain in East China. Procedia Social and Behavioral Sciences, 174, 36813688. https:/ / doi.org/10.1016/j.sbspro.2015.01.1091

Presti, D. (2015). Foundational concepts in neuroscience. New York: W. W. Norton \& Company.

Purdy, N. (2008). Neuroscience and education: how best to filter out the neurononsense from our classrooms? Irish Educational Studies, 27(3), 197-208. https:// doi.org/10.1080/03323310802242120

Racine, E., Bar-Ilan, O., \& Illes, J. (2006). Brain imaging. Science Communication, 28(1), 122-143. https://doi.org/10.1177/1075547006291990

Rato, J., Abreu, A., \& Castro-Caldas, A. (2013). Neuromyths in education: What is fact and what is fiction for Portuguese teachers? Educational Research, 55(4), 441-453. https://doi.org/10.1080/00131881.2013.844947

Sarroub, L. K., \& Quadros, S. (2015). Critical pedagogy in classroom discourse. In M. Bigelow, J. Ennser-Kananen (Eds.), The Routledge handbook of educational linguistics (pp. 252-260). New York: Routledge.

Sleek, S. (2018). Overturning myths in introductory psychology. Observer, 31(7), 21. Retrieved from https://www.psychologicalscience.org/observer/overturning-myths-inintroductory-psychology

Society for Neuroscience (2008). Neuroscience core concepts: The essential principles of neuroscience. Retrieved from http:/ / auth.brainfacts.sfn.org/brainfacts/aboutneuroscience/core-concepts 
Tardif, E., Doudin, P., \& Meylan, N. (2015). Neuromyths among teachers and student teachers. Mind, Brain, and Education, 9(1), 50-59.

https:/ / doi.org/10.1111/mbe.12070

\section{Authors' Biodata / Yazar Bilgileri}

Asil ÖZDOĞRU, Üsküdar Üniversitesi Psikoloji (İng.) Bölümünde öğretim üyesidir. Asil Özdoğru is an assistant professor in the Department of Psychology (Eng.) at Üsküdar University.

Nursena BALATEKİN, Üsküdar Üniversitesi Psikoloji (İng.) Bölümünden mezun olmuş bir psikologdur.

Nursena Balatekin is a psychologist who graduated from the Department of Psychology (Eng.) at Üsküdar University. 